\title{
O tradutor
}

implícito.

Consideraçōes

acerca da

translingualidade de Os Sertóes

का $x^{\circ}$

“Es gehört schon zum

Begriff eines Romans,

dass er keine

Nationalität haben muss"

BERTHOLD ZILLY

é crítico literário e

tradutor de Os Sertões,

de Euclides da Cunha,

para 0 alemão
(Friedrich Schlegel,

Literarische Notizen) ${ }^{(2)}$.
Propus o conceito de "tradutor implícito" pela primeira vez no curso de pós-graduação sobre "A tradução como análise, reinterpretação e universalização da obra literária: o caso de 'Os Sertões' e outros casos", ministrado no DTL da USP em agosto e setembro de 1997 depois em palestras no VII Encontro Nacional de Tradutores/I Encontro Internacio nal de Tradutores, São Paulo, USP, 10/9/1998, como também na Faculdade de Letras da UFRI, em 1/12/98. Agradeço sugestões de Margarethe Steinberger (PUC-SP), Willi Bolle (USP), João Cézar de Castro Rocha (UERI), Márcia Cavalcanti (UFR).

"Faz parte do próprio conceito de romance que ele não precisa ter nacionalidade"; tado de acordo com Neve Rundschav, 1996, p. 5. 


\section{A NECESSIDADE DO BOM ENTENDEDOR}

É um truísmo que textos literários, e não apenas estes, são escritos e sobretudo publicados para serem lidos, embora possam também ter outras finalidades. E é um truísmo, realçado e analisado mas não descoberto pela estética da recepção, que a leitura é constitutiva para a sua existência e sobrevivência. Não houvesse leitores, não haveria textos, haveria meras acumulações de letras em papel ou na tela do computador, sem sentido nenhum. Os textos, para existirem plenamente, precisam da sua concretização, atualização e, quando narrativos ou dramáticos, encenação mental pelo leitor, assim como as peças de teatro precisam da representação, os filmes da exibição e as partituras da execução, pelo menos imaginada, por parte de quem as entende $\mathrm{e}$ sabe evocar.

Os autores estão cientes disso, e portanto desde há muito não apenas se preocupam em discursar ou narrar, para informar, ensinar, entreter, edificar, para expressar seus afetos e desafetos, para transmitir a sua visão do mundo, para atacar ou se defender, mas se preocupam também com que tal mensagem ou história-os ensinamentos, a trama, as cenas, os personagens - sejam percebidas numa determinada perspectiva e lidas "corretamente". Nomeadamente os textos literários, mais do que os pragmáticos, pressupõem um leitor que seja um parceiro do autor, um colaborador, que entenda as intenções inscritas neles, que reconstitua e mobilize as suas idéias, alusões e emoções, que saiba preencher as suas elipses, lacunas e reticências. Vale de modo especial para esse leitor o ditado brasileiro "A bom entendedor meia palavra basta", porque a literatura, diferentemente de textos pragmáticos ou acadêmicos, vive justamente de meias palavras às quais é preciso acrescentar mentalmente a outra metade, para assegurar-lhes o/ou um sentido. Sem bom entendedor, capaz dessa operação complementar, a meia pala- vra seria uma não-palavra.

Por um lado os autores incitam a fantasia do leitor, da qual as obras, incompletas e abertas de certo modo, precisam; por outro lado procuram guiá-la. Naturalmente, pode haver também leituras a contrapelo, contra ou ao largo das intenções do autor, o que se dá muitas vezes em obras que perduram por séculos e que provam com isso a sua capacidade de revelar e ao mesmo tempo provocar inesperados significados. Com o mundo e os leitores em transformação, as obras são lidas à luz de novas experiências, interesses, idéias e perguntas, modificando parcialmente o seu sentido, numa dialética de mesmice e transformação, continuidade e diferenciação, que geralmente se chama vida das obras ou tradição literária e que os autores, quando muito, só vagamente podem prever ou pressentir com muita antecedência.

Para o conjunto das condições, exigências, orientações dirigidas ao leitor, prefigurando o seu papel até certo ponto, o teórico da literatura Wolfgang Iser, que sempre enfatizou a função constitutiva do ato de leitura para a existência das obras, propôs, nos inícios dos anos 70, o termo "leitor implícito" (3). São dispositivos e marcas que assinalam ao leitor de que modo ele deve ler um texto para realizar mentalmente grande parte das potencialidades do seu sentido, são fôrmas a serem preenchidas no ato da leitura, não totalmente configuradas, antes inacabadas, semi-abertas, exigindo criatividade e subjetividade daquele que lê. É de um leque de possíveis leituras, difícil de se definir precisamente, que cada leitor escolhe e realiza a sua leitura pessoal. O que vale para Fielding pode ser generalizado: "O papel do leitor inscrito no romance tem que ser percebido como condição de um possível efeito; de jeito nenhum determina as reações, mas prepara um âmbito de decisões seletivas que, uma vez tomadas, resultam em variedades individuais de realização $[\ldots]$ " (4).

O conceito de leitor implícito é deduzido por Iser sobretudo da prosa narrativa moderna, desde o Iluminismo, nomeadamente do romance com acentuada função 
referencial e apelativa, que constrói um mundo ficcional muito próximo do mundo empírico do leitor, tematizando, confirmando e questionando modos de encarar a realidade extraliterária. Essas sugestões para uma visão do mundo e atitudes em relação a ele pressupõem a colaboração ativa do leitor, carente porém, na opinião dos escritores, de um certo direcionamento.

O leitor implícito é uma espécie de contrapartida do narrador, geralmente tão invisível e anônimo quanto este, mesmo que o público seja apostrofado em fórmulas como "prezado leitor", num fictício diálogo, freqüente na literatura do século XVIII e da primeira metade do século XIX. Essas apóstrofes são apenas um dos possíveis recursos do autor para preestabelecer a atitude receptiva, um dos elementos portanto do leitor implícito que não é personagem, nem figura empírica. Também não é um leitor ideal que por sua vez seria capaz de realizar todas as instruções do leitor implícito, todos os significados intencionados pelo autor, e além disso todos os significados em que o autor não pensou nem poderia ter pensado, incluindo aqueles que se revelam ao longo da história. Pode naturalmente aparecer um leitor explícito, como personagem, por exemplo o leitor de cartas dentro de um romance, leitura ficcional que eventualmente também faria parte do estratagema do leitor implícito. Mesmo os textos herméticos "prevêem" o papel do leitor, para terem determinados efeitos, entre os quais a desejada impressão de hermetismo.

Há portanto uma duplicidade de estruturas: a) a do próprio texto, b) a das suas previstas leituras. Essas estruturas, que em realidade se fundem numa só, pois constituem o texto, condicionam uma infinidade de leituras virtuais, de que cada ato concreto de leitura só pode realizar uma parte, pois cada grupo de leitores e cada leitor individual têm as suas próprias experiências práticas e estéticas, a sua visão do mundo, seus valores e suas normas de conduta, além de variáveis estados de ânimo. Se o número de possíveis leituras de determinado texto é infinito, nem toda leitura é pos- sível, como também entre as muitas traduções possíveis de um texto há aquelas que correspondem mais e outras que correspondem menos às propriedades da obra. Estética e moralmente, um conto ou romance tanto confirma como transcende os valores e as expectativas do leitor que deve acompanhare realizar essas estratégias, mesmo que delas discorde parcial ou radicalmente. Com a crescente distância histórica entre a criação de uma obra e a sua recepção, o ato da leitura pode ser cada vez menos previsto e direcionado pelo escritor, de modo que com o tempo o leitor real vai ganhando maior autonomia em relação ao leitor implícito sem que este se torne desimportante (5).

\section{O TRADUTOR - UM ENTENDEDOR POR EXCELÊNCIA}

O tradutor evidentemente também é leitor, um leitor especialmente atento, assíduo, escrupuloso, crítico e exaustivo na tarefa da (re-)constituição dos significados da obra, um leitor potenciado. Pois ele é um Vorleser em vários sentidos, ou seja, um pré-leitor e pró-leitor, aquele que lê antes dos outros e pelos outros, sendo ao mesmo tempo um recitador, aquele que lê em voz alta para os outros, para uma audiência, prefigurando a sua compreensão do texto, espécie de preletor, que ensina como se deve ler. Entenda-se audiência principalmente no sentido metafórico, como leitorado, mas não exclusivamente, pois até os textos destinados unicamente a serem lidos em silêncio têm uma dimensão acústica realizada pela imaginação sonora do leitor, importante traço estilístico, um dos mais difíceis e dos mais necessários a ser transposto para o idioma-alvo, inclusive no caso de Os Sertões. A leitura tradutória condiciona as leituras de milhares de pessoas na língua de chegada, sendo grande, quase inevitável, o perigo de o tradutor agir, sem querer, como espécie de filtro, como censor em relação a certos aspectos do original. Pois o que o tradutor não entende,

\footnotetext{
5 W. Iser, ainda que enfatize a historicidade dos textos, parece dela eximir o leitor implícito. Ora, se tudo é historicamente mediado em um texto e nada nele é absolutamente invariável, o leitor implícito também deve ser um atributo histórico, parcialmente datado, não apenas genericamente, mas também concretamente em cada obra, evoluindo com ela e com as mudanças históricas das suas leituras.
} 
não capta, não intui, não adivinha pelo menos, e o que ele não repensa, reformula, recria, fica inacessível para o leitor da cultura de chegada, lesado no seu direito de ter acesso à quase-totalidade dos significados do original. Por outro lado, o modo como o tradutor entende uma obra nos seus detalhes e no seu conjunto vai prefigurar de modo decisivo as possíveis leituras da tradução e as idéias que os seus leitores fazem do original (6).

O desejo de fazer jus a esta tarefa de alta responsabilidade leva o tradutor a um papel quixotesco, o de um leitor hiperatento, hipersensível, com todas as antenas ligadas, aspirando a uma leitura completa, totalizadora, sonhando em realizar em sua mente todo o potencial de significados existente em determinada época e contexto social, incluindo a história da recepção, na medida em que esta entra na constituição do sentido da obra. O tradutor é parente espiritual de Pierre Menard, no conto de Borges, que não por acaso relê e reescreve justamente o Don Quijote, cuja “tradução”, embora literalmente idêntica ao original, tem um sentido bastante modificado, modernizado, atualizado diante dos aportes e perguntas de trezentos anos de história das idéias, decorridos desde a estréia do livro. Num segundo passo, que na prática frequientemente coincide com o primeiro, o tradutor procura oferecer ao leitor estrangeiro uma contrapartida equivalente aos múltiplos atributos e significados do original, restringidos, modificados e enriquecidos pela língua e cultura de chegada. Essa aspiração de ser um leitor ideal, que realizaria uma compreensão completa, é necessariamente um desejo vão, na melhor das hipóteses uma idéia regulativa, tão quimérica quanto a outra pretensão, a de dar a essa interpretação "completa" uma expressão estética em outra língua, preservando, contra todas as regras da lógica, a identidade da obra na diversidade das línguas, assegurando o maior volume possível de invariâncias entre original e tradução.

Diferentemente de outros "metaliteratos" que também lêem por e para outros leitores - o resenhista, o comentador, o professor, o historiador ou teórico da literatura-, parecido porém ao organizador de uma edição crítica, o tradutor não pode selecionar determinados trechos ou aspectos, mas tem que examinar e interpretar o texto todo. É um condenado, um acorrentado ao seu objeto de estudo, obrigado a segui-lo e a persegui-lo obstinadamente em todos os seus meandros e ramificações, detendo-se em minúcias e abrangendo o todo alternadamente, não podendo pular capítulos, frases, palavras ou nomes enigmáticos. A obra inteira, em sua macroestrutura como em sua microestrutura, em todos os seus pormenores até a última vírgula, tem que passar pelo crivo da sua crítica racional ou intuitiva, pois tudo é importante ou pode sê-lo, e para tudo, ainda que na prática seja impossível, ele tem que procurar uma equivalência na língua de chegada.

É como um cartógrafo que, diferentemente do geógrafo, não pode se limitar a estudar determinados aspectos de uma área, tendo que conhecê-la, pesquisá-la, e depois representá-la em sua quase-totalidade, de acordo com a escala, claro, "escondendo" porém o resultado das suas pesquisas no desenho dos mapas. Ao contrário do cartógrafo, porém, o tradutor não produz apenas um modelo, uma imagem abrangente, mas abreviada e simplificada do objeto estudado, ele produz ao contrário, por assim dizer, uma segunda paisagem nos moldes da primeira, na escala um a um, um parque barroco por exemplo, levado a outras latitudes e longitudes, básica mas não exclusivamente com os materiais do novo terreno, de acordo com a morfologia do novo meio. Como na recriação paisagística, na tradução nem todos os atributos do original se prestam igualmente ao traslado, o que não dispensa da obrigação de pesquisar e de tentar o inviável, pois às vezes só o exame escrupuloso revela a relativa intransponibilidade de certas expressões, compensadas muitas vezes em trechos vizinhos, ou parafraseadas, ou explicadas em notas ou em posfácio, de modo que o todo, grosso modo, é transponível sim (7). Pois a tradução é a arte do impossível. 
O tradutor, além de ler, como qualquer um, a olho nu, faz uma leitura por assim dizer radiográfica, sonográfica, química, usa lupa e microscópio, mas também binóculo invertido; ele procura, percebe e avalia, embora muitas vezes só intuitivamente, os atributos manifestos e encobertos do original, em todos os níveis, semântico, ideológico, sintático, alegórico, fônico, rítmico, eventualmente gráfico, prevendo e ponderando o efeito de seu traslado para a língua e cultura de chegada com suas coordenadas diferentes. No fim, tem-se familiarizado intimamente com a obra, está quase em casa nela, conhece suas qualidades e os seus defeitos, um pouco como o mordomo sabe dos vezos do seu amo, mas, diferentemente daquele, o tradutor não é tentado a perder o respeito pela instância a cujo serviço está, pois a conhece e valoriza em seu conjunto, relativizando os seus pontos frágeis. Ademais, o tradutor não é apenas o servidor, ele é, de um modo mais enfático do que o leitor normal, também o dono da sorte do original, podendo assegurar-lhe, graças ao seu trabalho de crítica e imaginação, graças à sua erudição, sensibilidade e perseverança, uma segunda vida, em outra cultura.

Apesar da necessária empatia, o tradutor precisa manter uma perspectiva de fora, principalmente no começo do trabalho, resistindo aos perigos da familiaridade não questionada, simpática em si, com que as obras, principalmente as clássicas, são lidas na cultura de partida. A imediata proximidade cultural e lingüística pode embotar o olhar do leitor, turvar a sua sensibilidade e argúcia, sugerir-lhe uma fácil compreensão, às vezes ilusória. Qualquer tradutor que pediu esclarecimentos a um falante nativo, mesmo erudito, da língua de partida já fez a experiência de que às vezes este nem sequer entendeu logo o problema, percebendo-o só depois de perguntas adicionais, explicativas, do tradutor (8).

Este tem que ser racional e analítico como o crítico acadêmico, perseverante e desconfiado como um detetive e ao mesmo tempo ingênuo e empolgado como o leitor comum para quem escreve em última aná- lise, admirando-se com tudo, pegando em tudo, revolvendo tudo, como se fosse uma criança erudita, mesclando uma abordagem de leigo com aquela do filólogo e crítico literário ou outro especialista, conforme o tipo e o assunto do texto. Não acha nenhum detalhe simplesmente natural e óbvio, tudo pode ter um segundo ou terceiro sentido, tudo pode não significar aquilo que a gente pensou no primeiro momento, tudo pode ter uma correpondência intra ou intertextual, importante de ser transposta para a versão de chegada, qualquer palavra repetida algumas vezes pode eventualmente ser uma palavra-chave, constituindo uma isotopia.

\section{INSTINTO DE UNIVERSALIDADE ${ }^{(9)}$}

O encontro de uma obra com outra cultura e língua revela aspectos e camadas de significados que geralmente não entraram na estrutura propositalmente elaborada do texto, mas que objetivamente nele existem. É com razão que se distingue a intenção do autor da intenção do texto, pois, por mais consciente e cerebral que seja o ato da escrita, nele entram intuições inconscientes, só parcialmente subjetivas, em grande parte coletivas, social e historicamente condicionadas, e uma vez pronta a obra, ela ganha dinâmica própria, intersubjetiva, por vezes surpreendente. Além disso, no decorrer da história da recepção, com o mundo circundante e os leitores em transformação, vai mudando também a intenção de um texto.

Se qualquer obra de qualidade estética e de veracidade social ou psicológica, enfocando e interpretando estruturas profundas da condição humana, tem uma orientação para públicos estrangeiros, em certos casos esse "excedente" de significados com respeito à língua e cultura de partida é premeditado. Há muitos indícios de que os autores do chamado boom da literatura hispano-americana dos anos 60 e 70, e especialmente os epígonos do realismo mágico, do tipo Isabel Allende, dirigiram-se
8 Em certos casos, estas perguntas do tradutor se devem a uma espécie de coerção lexical ou gramatical da língua de chegada que o obriga a uma desambigüização, ou seja, a um esclarecimento não necessário na língua de partida, por exemplo no caso do pronome alemão "sie" que pode significar "ela" "eles (homens)", "elas", "eles e elas", ou, em início de frase em que só há maiúsculas, pode até significar "o senhor" "a senhora", "os senhores (homens)", "as senhoras", "os senhores e as senhoras"; e nem sempre o contexto sintático deixa claro o exato significado, quando isso é sem importância para o autor. Por outro lado "irmãos" pode significar "Brüder" (irmãos ho mens) ou "Geschwister" lirmãos e irmãs), aí o tradutor alemão precisa interpretar e optar de acordo com outras informações no texto, mas dificilmente pode manter toda a ambigüidade cuja perda, se ela é estetica mente importante, pode prejudicar a tradução. Ou seja, nem sempre um acréscimo de trans parência e claridade é um benefício estético. A desambigüização no entanto pode ser também um ganho em plasticidade e sensorialidade, por exemplo no caso da tradução de "piano" em determina do contexto cultural, caracterizado por uma estética entre decadentista e vanguardista um estilo de vida aristocrático finissecular, em A Confissão de Lúcio, de Mário de Sá-Carneiro, em que entre os três termos genéricos que a língua alemã oferece - "Piano" "Klavier", "Flügel" - este último, que sig nifica "piano de cauda", é o mais condizente com o ambente social e artístico, além de ser o mais concreto, sugestivo e "sensorial", ao nível estilístico; ver Sá-Carneiro, 1995, p. 86

9 Ver Schwartz (1999), citando a interpretação que o crítico português Abel Barros Baptisto faz de Machado de Assis: "Não nego que haja em Machado referências a um contexto brasileiro, mas tenho ou tro tipo de indagação, saber o que ele pode dizer a um europeu no final do século $20^{\prime \prime}$ abordagem que também poderia ser a de um tradutor. $O$ título do artigo alude ao famoso ensaio "Instinto de Nacionalidade", em que Machado de Assis procura definir aspectos de brasilidade na literatura por volta de 1870; ver também Assis, 1986 
conscientemente a um público internacional. Talvez a aspiração ao reconhecimento além dos limites lingüísticos e culturais seja uma das marcas da literatura latino-americana, de Sarmiento a Borges, Fuentes ou García Márquez, e de um modo geral um traço das literaturas de regiões nãohegemônicas do globo, cujos escritores visam, como reminiscência mas também como desforra com respeito ao colonialismo, o público dos países metropolitanos, e através deles o mercado literário mundial. É que o centro intelectual dessas culturas ex-cêntricas se encontrou e de certa forma continua se encontrando fora delas e fora do seu continente, sobretudo em Paris, a "capital do século XIX" no dizer de Walter Benjamin, o que também vale para a inteligência latino-americana (10).

Há um leitor empírico muito próximo do tradutor que é o leitor estrangeiro conhecedor da língua do original. É um tradutor em potencial, pois ele também transfere, de propósito ou não, pelo menos parcialmente o espaço ficcional, os personagens, os valores morais e as qualidades estéticas de um texto para o seu próprio ambiente cultural e lingüístico, usando eventualmente, como o tradutor também, dicionários e outras ferramentas para se certificar de uma correta compreensão de detalhes. Atualiza o texto como leitor da língua de partida, mas também como espontâneo idealizador de uma tradução fragmentária, com que vai inserindo o livro estrangeiro na sua própria cultura. É compreensível que o leitor de fora se interesse principalmente pelas qualidades em que as obras transcendem as suas origens, por seus traços transculturais e trans-históricos, para cuja revelação tem especial competência interpretativa. Ora, essa legibilidade da obra para o leitor estrangeiro conhecedor da língua do original é indício de sua traduzibilidade. Quando fica manifesto que um autor e um livro têm algo a dizer a um público fora do âmbito da língua de partida e da época em que foi escrito, torna-se imprescindível a figura do tradutor. Este, como leitor e crítico de outro âmbito cultural, também procura aqueles traços em que o origi- nal, por mais enraigado que seja na sua língua, cultura, região, nação e época, transcenda essas divisas, revelando aspectos exemplares, universais e modernos, compreensíveis, apreciáveis e enriquecedores para integrantes de outras culturas. É natural que o tradutor realce esse apelo universal das obras, os seus traços transculturais e trans-históricos, aculturando-as e atualizando-as, sem tirar-lhes a historicidade, a pátina, a cor local, o matiz alheio.

$\mathrm{Na}$ era do pós-colonialismo cresce o número de autores das ex-colônias cuja escrita de certa forma é uma tradução ou transculturação, já que não escrevem em sua língua materna ou de infância mas em francês ou inglês, ou português, sobre a realidade e o imaginário de suas culturas de origem. Talvez a parte mais original e inovadora da literatura inglesa e francesa venha hoje da periferia, de autores não-europeus, tradutores de originais nunca escritos, fenômeno caracterizado por alguns críticos com o lema: "The Empire writes back"(11). Ou seja, a periferia dos antigos impérios coloniais conquista, no plano da produção literária, as metrópoles, o que aliás já se verificou na antiga Roma, onde a maioria dos escritores do baixo-império vinha das províncias. É também enquanto críticos e intérpretes que intelectuais de culturas não-hegemônicas, inclusive de antigas colônias, enriquecem e aprofundam a vida literária européia e a norte-americana.

\section{DO LEITOR IMPĹ́CITO AO TRADUTOR IMPLÍCITO}

Na medida em que o tradutor é um leitor por excelência, com ambição de se aproximar do leitor ideal, é de se perguntar se o conceito iseriano pode ser aplicado a ele, de modo que haveria o leitor-tradutor implícito, e portanto o tradutor implícito. $\mathrm{O}$ papel do leitor previsto dentro do texto teria como corolário o do tradutor igualmente previsto, embora menos manifesto, um feixe de orientações e recomendações de 
como determinada obra deve ser lida por falantes de outras línguas e como para estas deve ser trasladada.

Parece procedente a crítica de Terry Eagleton de que Iser teria contemplado unilateralmente um leitor liberal, tolerante, aberto, culto, refinado, e teria considerado inadequadas as leituras de pessoas menos instruídas ou menos abertas, sem capacidade de desfrutarem as relações intertextuais e as qualidades diferenciais. O leitor iseriano, principalmente o do século XX, de fato é concebido como um leitor quase ideal, capaz de realizar criticamente as recomendações do leitor implícito, dispondo de ampla cultura geral, abstraindo parcialmente de sua subjetividade, com uma atitude que poderia ser caracterizada pela fórmula kantiana do "prazer desinteressado". É um conceito que promove uma implícita exclusão dos operários como também de pessoas fortemente engajadas emocional ou politicamente (12).

Quanto ao leitor-tradutor, no entanto, cabe sim concebê-lo como leitor aberto, culto, conhecedor das tradições poéticas, retóricas, filosóficas, morais a que se refere implícita ou explicitamente o escritor, perfeitamente apto ao papel de leitor previsto na obra. Se Eagleton tem razão em não descartar a legitimidade de leituras com menos experiência literária, senso histórico e abertura ideológica, se ele considera pessoas pouco instruídas como leitores competentes mesmo que só realizem pequena parte dos significados de um texto, isso no entanto não vale para o leitor-tradutor, que não deve poupar esforços para justamente tentar aproximar-se do leitor ideal. Talvez o tradutor seja quem mais completamente segue as orientações do leitor implícito, transcendendo-o ao mesmo tempo, detectando especialmente aqueles traços que se dirigem a um público bem maior do que o da cultura de origem, a um leitorado virtual de todas as línguas e épocas, em última instância: a todo o gênero humano. Entende as orientações do autor para o leitor, principalmente os seus aspectos translinguais e transculturais, mesmo que não tenham sido premeditadas, como su- gestões para a tarefa do tradutor. O leitor implícito, num sentido enfático e extensivo, se nos afigura portanto ao mesmo tempo como tradutor implícito.

Se qualquer leitura é uma concretização, recriação e encenação (13), isso mais vale ainda para a tradução que é, como vimos, um ato aprofundado e ampliado de leitura, mais crítico e ao mesmo tempo mais empático do que o ato da leitura normal. O mundo ficcional que o tradutor evoca e presentifica não permanece imaginado e incompleto como o do leitor normal; ele, ao contrário, é objetivado e materializado em um novo texto capaz de evocar em outros leitores aproximadamente o mesmo mundo ficcional, através de equivalentes procedimentos estéticos, que é enquadrado em outro contexto cultural e outro mundo vivenciado, originando por isso novos significados. O tradutor é leitor na medida em que evoca o mundo ficcional no ato da leitura, seguindo crítica e criativamente as instruções do leitor implícito, mas ele também é autor, na medida em que dá palpável realidade lingüística a esse mundo ficcional. Vai embutir no texto de chegada, por sua vez, um conjunto de dispositivos para outros atos de leitura, um segundo leitor implícito, calcado no do texto de partida, de acordo com as estratégias de apropriação e recriação do tradutor, que podem oscilar entre os pólos extremos do total estranhamento e da total assimilação com respeito ao novo âmbito cultural. O leitor da tradução por sua vez realiza significados que resultam da realização que fez o tradutor dos significados do original, sendo portanto um re-leitor que só pode evocar aquilo que o seu pré-leitor evocou e fixou, o que não exclui uma interpretação própria, parcialmente autônoma com respeito ao tradutor, que deve, por mais necessária que seja a sua visão subjetiva, manter, na medida do possível, as ambigüidades, polissemias, indefinições da obra, permitindo uma multiplicidade de leituras e interpretações. A tradução bem-sucedida é quase tão polifônica, pluridimensional, sugestiva quanto o original, emancipando-se parcialmente da intenção e do leitor implícito
12 Eagleton, 1997, pp. 107 e segs

13 Sobre o conceito de encenação ver Iser (Rio de Janeiro, 1996, pp. 356-631 
criado pelo tradutor, desdobrando-se em outros rumos, num processo de objetivação que lembra o do original.

O tradutor implícito, na medida em que abrange um feixe de orientações que valem também para o leitor de línguas e culturas estrangeiras, seria o denominador comum dos elementos de translingualidade, transculturalidade, traduzibilidade, inscritas nas obras, já que estas não esgotam o seu sentido na real ou possível recepção pelo leitorado-alvo, tendo um superávit de significados, transcendendo a época e a comunidade lingüística para que foram escritas. Essas instruções para a tarefa do tradutor, como aquelas para o ato da leitura, não são imutáveis; elas, pelo contrário, podem mudar ao longo dos tempos, de modo que o tradutor, com toda a atenção e sensibilidade de que é capaz, vai tateando, olhando, escutando o texto para perceber como ele quer ser lido e traduzido no tempo presente e para determinada cultura-alvo.

\section{OS ORIGINAIS PRECISAM DAS TRADUCŌ̃ES?}

Poder-se-iam alegar algumas objeções. Uma diferença entre leitor implícito e tradutor implícito seria a seguinte: se o ato da leitura sem dúvidaé constitutivo para a existência dos textos, se ele está previsto e prefigurado na sua composição, estilo, temática, perspectiva narrativa - o ato da tradução aparentemente não oé. A plausibilidade de se conceber o papel do leitor previsto nas obras não valeria portanto para o papel do tradutor. Os originais, pelo menos à primeira vista, podem prescindir da tradução, o que fica provado pelo fato de que há milhares, se não milhões de obras não traduzidas na história das literaturas. Foram ou são lidas, sim, precisam ser lidas para ter plena realidade, mas não necessariamente ser traduzidas. Ser lido ou não ser lido é uma questão fundamental para qualquer texto; ser traduzido ou não poderia parecer, do ponto de vista do autor, uma circunstância não essencial, uma questão de vaidade ou de interesse econômico. Por isso estratégias explícitas ou implícitas no sentido de orientar o leitor estrangeiro e o tradutor seriam desnecessárias.

A importância da tradução para a vida dos originais é uma temática ampla e muito discutida sobre a qual aqui convém esboçar apenas umas poucas observações. Talvez não seja supérfluo chamar a atenção para um fato tão familiar que fica despercebido fora da área filológica: os próprios materiais de que são construídos os textos - os idiomas e o que neles se objetiva, as convenções literárias, os parâmetros interpretativos, os conhecimentos e idéias das mais diversas áreas - se devem a uma longa tradição tradutória, no sentido próprio e figurado. As línguas européias, e outras provavelmente também, em maior ou menor grau, são resultados de múltiplos processos de tradução, de empréstimos lexicais, empréstimos semânticos, decalques de provérbios, influências sintáticas, imitação e recriação de metáforas, adoção e assimilação de mitos, provérbios, crenças, ideologias que sempre aparecem em forma de linguagem (14). Esse parentesco que se deve à mesmice das origens grecolatino-francesas, bíblicas, científicas das línguas européias e aos contínuos intercâmbios entre elas, garante-lhes um grande patrimônio cultural e terminológico comum que tende a se universalizar pelo mundo afora, hoje sob a égide do inglês estadunidense. A própria ferramenta de que se serve um escritor, seja latino-americano, seja alemão ou inglês, compartilha portanto um enorme fundo de conceitos, imagens e modos de pensamento com outras línguas e culturas, excedendo já por isso o seu próprio âmbito lingüístico e cultural, o que facilita a tarefa do tradutor, apesar da ameaça dos falsos amigos. As línguas européias em grande parte são criações de tradutores, principalmente a partir do latim. Quem escreve em português escreve parcialmente em "europês", ou “ocidentês", ou seja, a sua obra em muitos de seus elementos lingüísticos e intelectuais provém de outras línguas e culturas e a elas se remete. 
Nem todos os escritores acentuam esses traços translinguais tanto quanto Euclides da Cunha, mas nenhum os pode ignorar. Seria dificílimo escrever um texto de alto nível estético e significativo com respeito à condição humana para uma só comunidade lingüística, pois o próprio material linguiístico e as formas literárias, além das mensagens por assim dizer antropológicas, iam transbordá-la. As obras, principalmente as do mesmo âmbito civilizatório, já estão, por sua translingualidade e transculturalidade, com um pé em outras línguas e culturas, pedindo e suscitando traduções, para complementar os elementos tradutórios que lhes são inerentes (15). É verdade que um elemento transferido de um sistema de signos para outro tem seu valor modificado, de modo que geralmente não há identidade total, mas sim semelhanças micro e macroestruturais. Qualquer livro brasileiro é, entre outras coisas, resultado de três mil anos de intercâmbios culturais e processos tradutórios, cada vez mais contínuos e densos, sem os quais não haveria as línguas nem os modos de pensar que temos, nem os textos, e muito menos as suas traduções. O fundo comum de meios de expressão é particularmente grande entre as línguas neolatinas, dominadas há séculos pelo francês, que até hoje tenta impor-lhes os seus neologismos, disputando o seu poderio com o inglês.

Se a história da recepção de uma obra não pode prescindir dos atos de leitura e da crítica literária que os acompanha, dificilmente pode prescindir da tradução que também é crítica, comentário, exegese, marcando fortemente a fortuna dos livros, seu papel na vida literária fora do seu âmbito lingüístico, mas freqüentemente com repercussões dentro dele. Um Shakespeare nunca traduzido não seria o Shakespeare que existe hoje na Inglaterra, apesar do papel hegemônico do inglês. Sem tradução não haveria tradição literária internacional, quase não haveria intertextualidade além das fronteiras lingüísticas, não haveria a Weltliteratur que Goethe idealizou também como expressão do alcance universal da poesia, no sentido mais amplo da palavra, e para o qual colaborou também como tradutor e teórico da tradução (16). Cada uma das literaturas nacionais ou regionais seria infinitamente mais pobre, e as obras que hoje fazem parte do patrimônio cultural da humanidade praticamente não existiriam ou seriam bem diferentes. As obras clássicas da Antigüidade, do antigo Israel, dos indianos, dos chineses, também da Idade Média, das chamadas línguas menores, do islandês, dos idiomas bálticos por exemplo, todas elas produtos de trocas culturais e traduções, seriam, não fossem traduzidas por sua vez, esquecidas, a não ser para um número ínfimo de conhecedores. Não pertenceriam realmente à vida literária mundial, no sentido de um processo de intercâmbios e discussões entre texto, crítica, público. Seriam uma Bela Adormecida à espera do seu príncipe, o tradutor, que as resgatasse e as fizesse reviver, idênticas e transfiguradas ao mesmo tempo.

O tradutor é duas vezes crítico, na medida em que faz uma análise e interpretação, seja racional seja intuitiva, do original. Ademais, o próprio texto, em que ele objetiva e ao mesmo tempo "esconde" essa crítica, transformando-a em forma estética, também constitui um comentário crítico, embora não analítico, em relação ao original, além de ser sua reprodução metamorfoseada, uma transcriação, como diz Haroldo de Campos, sendo qualquer tradutor, necessariamente, um crítico pelo menos implícito (17). A sua interpretação pode ser valiosa também para o conhecedor da língua de partida, de modo que só em parte o original e a tradução se substituem mutuamente, fazendo-o cada vez menos à medida que ganha importância a função poética em um texto (18). Sendo assim, é particularmente esdrúxula a opinião, muito difundida entre "cientistas da literatura" na Alemanha, de que só deve ler traduções quem não conhece a língua do original, de modo que bibliotecas na área de letras não precisariam comprar traduções, já que os estudiosos conhecem ou deveriam conhecer as respectivas línguas originais. Deixam-se guiar pela ingênua idéia de que a tradução seria apenas uma

\footnotetext{
$5 \mathrm{Na}$ crítica literária e nos estudos culturais de hoje em dia muitas vezes se usa o termo tradução ou tradutor numa acepção semimetafórica, para caracterizar relações intertex tuais ou intratextuais de termos e de idéias, que geralmente de fato têm elementos de trodução no sentido próprio /ve Villaça, 1998).

16 Ver Berman, 1984, pp. 87 110

17 Ver Campos, 1992, pp. 31 48; Campos, 1989, pp. 94 5.

18 À medida que fica mais impor tante a função referencial, au menta o grau de traduz bilidade e de substituibilidade do original; ver Jakobson, 1969, pp. 118-62.
} 
19 Benjamin, 1994; ver também os ensaios de Jacques Derrida Carol Jacobs, Paul de Man outros sobre o ensaio de Beniamin, em Hirsch (1997).

20 Störig, 1973, p. VIII. A obser vação de Jean Paul 11763 1825 ) pode ser entendida como uma espécie de autolegitimação, pois as sua próprias obras, best-seller na Alemanha da época, por sua tantasia transbordante, seu humor um pouco excêntrico, com notas melancólicas, e sua sensibilidade Biedermeier, espécie de romantismo idílico caseiro, típico da burguesia alemã, principalmente do seu componente feminino, na primeira metade do século XIX, de fato se opõem ao traslado a outras línguas, apesar de sua inegável qualdade literária. Há quem diga que Aleksander Púchkin, um dos maiores autores russos de todos os tempos, também intraduzivel, consistindo sua maior qualidade na sua aura incorpórea, criada pelo estilo que seria banalizado em qua quer tradução: ver Viktor Jerofejew, "Das Rätsel de Unübersetzbarkeit: Gab es Puschkin überhaupt? Zu seinem 200. Geburtstag am 6. Juni", in FrankfurterRundschau, 5/6 1999, p. ZB 2.

21 Jakobson, 1969 imperfeita reduplicação do original, muleta daquele coitado deficiente cultural que não lê fluentemente as grandes obras nos idiomas originais.

Se, não apenas na literatura, mas também na filosofia, teologia, jurisprudência, na própria crítica literária por vezes, os clássicos campos da hermenêutica, é praxe corrente e elucidativa usar, na leitura de textos difíceis, polissêmicos, herméticos, um comentário descritivo ou analítico, por que não se valer também de um comentário palavra por palavra, frase por frase, em forma de tradução que quase sempre é uma elucidação, uma atualização e universalização, com parcial desambigüização sobretudo tratando-se de textos nãoficcionais? Um exemplo clássico é justamente o instigante mas hermético ensaio de Walter Benjamin, “A Tarefa do Tradutor", que desdobra melhor o seu potencial de significados quando se começa a traduzi-lo ou a estudá-lo em traduções já feitas, mas não acabadas, pois uma tradução nunca fica pronta (19). Um dos métodos mais eficientes para entender um texto que resiste à imediata compreensão é traduzi-lo, sendo o tradutor o guia do crítico, e viceversa, motivo pelo qual o autor do presente artigo empreendeu a transposição de $O s$ Sertões ao alemão.

A traduzibilidade portanto não é uma circunstância exterior e aleatória das obras. Estas, principalmente as mais significativas e expressivas, as de mais alto nível estético, as mais ricas e concretas em experiências humanas, as de mais rico potencial de sentidos, essas sim pedem, exigem, mas também desafiam e repelem a tradução. Pois justamente por serem bem-sucedidas ao nível formal, arraigadas em sua cultura, lançando mão do rico instrumental de sua língua, são particularmente difíceis de se traduzir, um quebra-cabeças para o tradutor. O escritor romântico alemão Jean Paul, na sua Vorschule der Asthetik (Estudo Preliminar de Estética), chegou a afirmar que as obras de fácil traduzibilidade não merecem uma tradução, pelo que se poderia deduzir que só as intraduzíveis é que a merecem (20).

\section{TRADUTOR COMO CO-EDITOR DO ORIGINAL}

Um dos efeitos mais frequientes e menos percebidos que a tradução exerce sobre o original é de ordem filológica: concerne à escolha e ao estabelecimento da própria versão a ser traduzida.

Como qualquer leitor, o tradutor, no caso de uma obra com várias tiragens e edições, tem que fazer uma opção e, tratando-se de uma edição crítica, tem que optar de vez em quando entre várias lições dos mesmos trechos, e mesmo que haja uma única lição ele pode tropeçar em palavras ou frases que lhe parecem corrompidas, pondo-lhes a nu sua frágil consistência filológica. Pode se tratar de erros ortográficos, lexicais ou gramaticais, raciocínios ilógicos ou equívocos factuais, por exemplo a menção de Hannover como porto marítimo em romance brasileiro dos anos 70, sendo intencionado evidentemente Hamburgo, imperfeições que o leitor, percebendo-as, vai emendar tacitamente, ao passo que outras emendas exigem pesquisas, ponderações e hesitações. Se o leitor geralmente pula um trecho que lhe parece corrompido, essa saída é barrada ao tradutor que não pode se esquivar à obrigação de decidir qual a versão, qual a lição, qual a emenda em que deve basear a versão de chegada. Tem a responsabilidade de escolher as lições mais condizentes com a vontade do autor, com a atualidade histórica e com o grau de instrução do leitor-alvo.

Quanto mais um texto é marcado pela forma, ou seja, pela função poética, na acepção de Jakobson (21), mais problemáticas são essas correções e conjecturas, de modo que muitos editores hesitam em emendar trechos defeituosos ou problemáticos, principalmente quando se trata de uma obra clássica cuja consagração parece se estender aos próprios erros. A pretensão do tradutor de produzir um texto esteticamente coerente, em que cada detalhe deve ter função e sentido, eliminando erros desvirtuadores da intenção do autor, é de execu- 
ção particularmente difícil e requer especial cautela em textos de vanguarda do século XX, já que o desvio das normas lingüísticas, estilísticas e lógicas faz parte de sua qualidade estética. Seria desejável que fosse permitido ao tradutor prestar contas desse seu trabalho filológico e editorial em forma de notas finais, pois ele parte de um original que a rigor, na sua exata e completa forma, em todos os seus detalhes, nunca foi impresso, que ninguém acharia se o procurasse, que é uma versão invisível, embora elaborada conscienciosamente. Exagerando um pouco, pode-se dizer que cada tradutor traduz o seu próprio original que, com suas emendas só reconhecíveis indiretamente, através da tradução, pode eventualmente repercutir em reedições do texto de partida, o que já aconteceu com a edição crítica de $O$ s Sertões. Os tradutores não fazem alarde dessa sua tarefa de filólogo e editor crítico, por ser tão comum e aparentemente banal. Em verdade, porém, é uma das várias maneiras de que a tradução lança luz sobre o original, revelando os seus atributos intrínsecos.

\section{A TRADUÇÃO NAS ENTRELINHAS, SEGUNDO BENJAMIN}

Sobre várias das questões de que temos tratado, Walter Benjamin teceu instigantes reflexões no seu famoso ensaio "Die Aufgabe des Übersetzers”. Seria temerário tentar aqui analisar um texto que há décadas vem desafiando os estudiosos, opondo-se a uma exegese unívoca, mantendo um certo hermetismo até hoje. Mas deixem-me tirar uma idéia interessante, para a nossa temática, dessa "Tarefa do Tradutor" cujo título aliás também pode significar "A Desistência do Tradutor" ou "A Capitulação do Tradutor", como já foi observado por vários críticos e como vocês talvez saibam. Já na primeira frase porém o autor postula a total indiferença da obra com respeito à leitura e portanto à tradução, aparecendo à primeira vista como ra- dical antípoda da futura estética da recepção de que Wolfgang Iser será um dos expoentes. Esboça uma visão essencialista, quase teológica e messiânica da arte, mas ao longo da argumentação enfatiza por outro lado a radical historicidade das obras, as mudanças do seu sentido com as mudanças dos tempos, o que já soa bem menos essencialista. Dá pouca importância à mensagem, ao conteúdo, à função referencial, como diria Jakobson, realçando a forma, reivindicando uma "formvolle Ubersetzung", uma tradução marcada pela forma (22).

Admite Benjamin por um lado que certos significados ficam encobertos nos originais, esperando pela sua tradução, como que por um passe de mágica, para serem desvendados e animados, avivados; por outro lado acrescenta a restrição, para logo questionar a importância do tradutor, que o seu trabalho nada significa para as obras originais, o que não deixa de ser uma certa contradição, mesmo porque admite também que as obras vivem e sobrevivem, como substâncias orgânicas, como seres vivos, em grande parte através das traduções. O que vive pode mudar, crescer, amadurecer, "ter um amadurecimento tardio, posterior", pode envelhecer, ou morrer talvez, o que o autor não diz mas o que se pode deduzir. $O$ termo alemão nachreifen poderia significar também que as obras não estão totalmente maduras na hora do seu acabamento, e que tal como as maçãs, colhidas duras e azedas para ficarem comestíveis no decorrer do inverno, ou as bananas, colhidas verdes e exportadas dos trópicos para a Europa, precisam amadurecer posteriormente para poderem ser"consumidas" (23). Talvez até se possa dizer que os textos nunca ficam totalmente acabados, já que precisam da colaboração do leitor, nem ficam totalmente maduros para sempre, já que uma nova constelação histórica pode eventualmente envelhecê-los ou, ao contrário, rejuvenescê-los.

De qualquer forma eles sobrevivem nas traduções que garantem a sua "glória", termo no fundo incompatível com uma visão essencialista da obra literária, que, se real-
22 Benjamin, 1955, p. 53

23 Ver Benjamin, 1955, p. 44. A comparação com as bananas naturalmente é anacrônica ou talvez até indigna de assunto ão elevado, mas talvez não fora do lugar, pois também são produtos transpostos para ou tro contexto social e cultural ficando idênticos etransformando-se ao mesmo tempo, tanto física como simbolicamente. A. Berman (Berman, 1996) ob serva que as próprias traduções não conheceriam essa Nachreife, seriam por assim di zer maduras com o seu acabamento, envelhecendo mais rá pido do que os originais, uma constatação em princípio pla sível, que no entanto não deve ser absolutizada; por exemplo as traduções de Homero por Johann Heinrich Voss, do fim do século XVIII, até hoje são as mais lidas em língua alemã; por outro lado as traduções de obras gregas, como da Antígone de Sófocles, por Höderlin, também de duzentos anos atrás, só no nosso século revelaram toda a sua qualidade e modernidade como aliás demonstra o próprio Berman 11984, pp. 250 781, de modo que quando Brecht fez uma adaptação daquela tragédia, apoiou-s na tradução de Hölderlin. 
24 Benjamin, 1955, p. 48; ver também Benjamin, 1994, pp. 22 e 23 , onde a versão portu guesa reza: "Esta [a tarefa do tradutor] consiste em encontrar para a língua na qual se traduz, determinada intenção partir da qual nela é desperto do o eco do original. [...] A tradução não se vê, como obra de arte verbal, por assim dizer, na floresta interna da língua: mantém-se fora desta, frente a ela e, sem a penetrar, convoca $o$ original para nela ingressar no único lugar onde eco pode dar a ouvir a obra da língua estrangeira em sua pró pria língua. Sua intenção se dirige a outro objeto que não apenas o da obra de arte verbal, a saber, a uma língua em sua totalidade, a partir de uma única obra de arte numa língua estrangeira, mas é em si mesma diversa: a intenção do es critor é ingênua, primeira, intutiva, a do tradutor derivada, última, intelectual. Pois o que realiza seu trabalho é o motivo maior de uma integração da muitas línguas na língua verda deira".

25 Idem, 1994, p. 29

26 ldem, ibidem, p. 32.

27 Barck, 1994, pp. 38-9

28 Benjamin, 1994, p. 30 Pannwitz era membro do seleto círculo de literatos em torno do poeta Stefan George 11868 1933) que, com atitude elitista e autoritária, propagava uma poesia cultual, hierática, hermé tica, embora voltada também a modernidade, recebendo muitos impulsos do simbolismo francês.

29 Idem, ibidem, p. 30. mente independesse da leitura, também poderia e deveria prescindir da glória. Se esta lhe é importante, a tradução também o é, sendo o original sozinho incapaz de gerála e mantê-la. Mais importante é outro papel das traduções. Mesmo que elas fossem desnecessárias para as próprias obras literárias tomadas isoladamente, seriam necessárias sim para a relação entre as línguas pós-Babel, de tendências não apenas centrífugas mas também centrípetas, convergindo no intercâmbio entre as literaturas, na vida literária mundial. Esta vive das divisões mas também da permeabilidade entre as línguas, reforçando-a, acentuando a profunda afinidade entre elas, menos em relação aos próprios significados do que no modo de significar, na sua capacidade de simbolizarem o mundo e de permitirem a comunicação entre os homens. Cabe ao tradutor tornar transparente essa aspiração das línguas pela complementação por outras, inerente aos textos originais. A totalidade das intenções das línguas que vão além delas mesmas seria a língua pura, talvez: a linguagem humana com todas as suas potencialidades expressivas e comunicativas, a utopia de a humanidade ter uma língua só, infinitamente rica, mais empiricamente aquilo que as línguas mais diversas têm em comum, graças às faculdades universais do intelecto humano, o que mais tarde seria aliás uma preocupação da gramática gerativa, de Noam Chomsky.

O tradutor teria a tarefa justamente de colaborar com essa imensa obra de aproximação das línguas, tornando transparentes as estranhezas e as convergências entre elas, juntando fragmentos para a grande obra da língua pura, utópica, messiânica. As traduções são etapas nesse caminho, cujo destino é inalcançável. O tradutor deve, segundo Benjamin, encontrar através do seu trabalho aquela intenção dirigida para o idioma de chegada, a partir da qual nele é despertado o eco do texto de partida (24). "Resgatar em sua própria língua a língua pura, ligada à língua estrangeira, liberar, pela transcriação (Umdichtung), a língua pura, cativa na obra, é a tarefa do tradutor" (25). As obras se transcendem a si mesmas e ao seu âmbito lingüístico através da sua traduzibilidade: "Pois todos os grandes escritos, em qualquer grau, e os escritos sagrados em grau máximo, contêm nas entrelinhas a sua tradução virtual" (26). O teórico da literatura Karlheinz Barck, analisando Benjamin, fala da "traduzibilidade como propriedade inscrita em toda obra original de valor [...], algo como uma advertência (ou uma convocação) do original a exigir a tradução" (27).

Temos aí, em outras palavras, a idéia do tradutor implícito, um conjunto de marcas e balizas para o tradutor na sua lida para aproximar a obra de uma hipotética língua geral da humanidade, atendo-se e dando seguimento aos seus traços de translingualidade e traduzibilidade. E naturalmente ele resgata essa transcendência da obra para além do seu âmbito lingüístico tanto melhor quanto mais procura transmitir a sua forma, justamente aquilo que é mais difícil e quase impossível de se transmitir, introduzindo na obra de chegada traços e elementos do original, tornando-a provocadoramente estranha na sua nova familiaridade lingüística, deixando nela transparecer traços formais da língua e cultura de partida. Pois o tradutor, como reivindica Rudolf Pannwitz, citado por Benjamin, deve "indianizar, helenizar, anglicizar o alemão”, e, por que não, também abrasileirá-lo, acrescentamos nós (28). "A verdadeira tradução é transparente, não oculta o original, não o ofusca, mas faz com que caia tanto mais plenamente sobre o original, como se forçada por seu próprio meio, a língua pura. Isso se obtém sobretudo pela literalidade na transposição (Ubertragung) da sintaxe, e justamente é a literalidade o que mostra a palavra, e não a frase, como o elemento originário do tradutor. Pois a frase é o muro diante da língua do original; a literalidade, a arcada" (29).

Sabemos que essa idealização da versão interlinear não pode ser tomada ao pé da letra, e nem o próprio Benjamin o fez enquanto tradutor, é uma hipérbole quase barroca, pois, se realizada rigorosamente, tornaria o texto de chegada hermético, deixaria de promover o seu perviver e invia- 
bilizaria o seu papel transcendente em relação ao original, rumo à língua pura. É possível sim, por exemplo no alemão, com sua relativa liberdade na colocação das palavras, imitar parcialmente a seqüência dos elementos lexicais do original, forçando um pouco as suas regras sintáticas, sem quebrálas realmente. Pois seria problemático tornar estranho ou até incompreensível na tradução aquilo que no original é corriqueiro e nada chamativo, de modo que a estranheza, além de caracterizar a tradução de um modo geral, dentro dos limites de uma inteligibilidade condizente com o gênero e o assunto, só deve se aplicar àquilo que também é estranho no original (30). Assim haveria dois tipos de estranhamento, caracterizando por um lado o texto-alvo como um todo, na medida em que nele vêm à tona atributos do original e da sua cultura, e por outro lado o desvio, no original, de determinados detalhes lexicais e sintáticos com respeito à norma e ao horizonte de expectativa, tendo o tradutor que recriar essa qualidade diferencial. Para caracterizar a tradução que permite a transparência das qualidades do original, reivindicada por Benjamin, caberia uma metáfora bastante apreciada hoje em dia, a do palimpsesto (31).

As convergências entre Benjamin e a posterior estética da recepção com respeito à tradução foram estudadas por Haroldo de Campos num artigo em que se aproxima da idéia do tradutor implícito: "O texto traduzido, como um todo (como um ícone de relações intra-e-extratextuais), não denota, mas conota seu original; este, por seu turno, não denota, mas conota suas possíveis traduções. Ocorre assim uma dialética perspectivista de ausência/presença. A tradução é crítica do texto original na medida em que os elementos atualizados pelos novos atos ficcionais de seleção e combinação citam os elementos ausentes; o original, por sua vez, passa a implicar as suas possíveis citações como parte constitutiva de seu horizonte de recepção (a sobrevida do original, o seu perviver, na terminologia de W. Benjamin)" (32).

A idéia do tradutor implícito está por assim dizer no ar há muito tempo. Quando
Antoine Berman, outro conhecedor da obra benjaminiana, disse que "toute oeuvre prévoit sa traduction dans sa structure" (33), ele parece prefigurá-lo. Vai na mesma direção uma outra frase do falecido tradutor e teórico francês:

\section{“Le rapport interne qu'une œuvre entretient} avec la traduction (ce que'elle contient en soi de traduction ou de non-traduction) détermine idéalement son mode de traduction interlangues, ainsi que les 'problèmes' de traduction que'elle peut poser. Ou encore: le rapport que sa langue entretient avec une ou plusieurs autres langues [...] détermine sa traduction dans une autre langue" (34).

\section{EUCLIDES TRADUTOR}

A idéia da tradução é uma presença na vida e na obra de Euclides. O próprio autor é um viajante entre dois mundos, é mediador, explicador, intérprete, 'Ubersetzer e Ubersétzer, barqueiro entre duas margens e também trasladador de mensagens entre duas linguagens e culturas. Tem valor simbólico a atividade simultânea desse engenheiro letrado como construtor de uma ponte atravessando o Rio Pardo, no interior paulista, e como autor de Os Sertões, livro destinado a atravessar o abismo de ignorância e incompreensão entre a população sertaneja e os intelectuais do litoral. É com boas razões que se usa a metáfora da ponte para caracterizar a atividade tradutória, ponte que, ainda que à primeira vista de mão única, funciona nos dois sentidos, visto que, como já dissemos, a tradução também lança luz sobre o original (35).

Para tornar a "terra ignota" menos ignota, Euclides basicamente se vale de dois métodos complementares: aproveita a sabedoria e a terminologia do sertanejo, citada em grifos ou não, para denominar, descrever e explicar o sertão como natureza e sociedade, o seu clima, solo, fauna, flora, agricultura, artesanato, cultura, religião, violência. Deixa-se encantar por vezes,
30 A tradução de Lemprière's Dictionary, de Lawrence Norfolk, para o alemão foi criticada justamente por conferir estranheza a trechos nada estranhos em inglês; ver Gerzymisch-Arbogast, 1994 pp. 18 e segs.

31 Rosemary Arrojo, como outros teóricos pós-modernos, aplica esse termo à própria obra literária, que seria palimpsesto na medida em que não é uma estrutura estável de signos significados, mas carente de ser reinterpretada, reescrita de certa forma, em cada ato de leitura, de modo que camadas de interpretacões vão se superpondo ao longo dos tempos. O original, cujo conceito começa a se dissolver parciamente, portanto é uma "máquina de significados em potencal" (Arrojo, 1986, p. 23), metáfora bem elucidativa. A do palimpsesto porém talvez caba melhor à tradução, através da qual se pode vislumbra anto a história da recepcão as camadas de sucessivas in terpretações, como também o estilo do original, além do seu conteúdo referencial, de modo que a tradução seria o palimpsesto dos palimpsestos.

32 Campos, 1989, pp. 94-5.

33 Berman, 1995, p. 25, nota 25

34 ldem, 1985, p. 113. Esta ci tação se refere à tradução do Paradise Lost de Milton por Chateaubriand e ao estreito diálogo daquele com o latim o hebreu, o grego e o italiano, no que foi seguido por seu tradutor. Não fica claro se Berman, quando estudou Benjamin, referiu-se à sua idéia da traduzibilidade inscrita nas obras, uma vez que o seu texto publicado sobre o ensaio de Benjamin só é fragmento de artigo maior, ainda não publicado. ver idem, 1996. Devo o conhecimento deste texto ao psicanalista Marcelo Marques.

35 Ver por exemplo o título do livro de losé Paulo Paes, Tradução: a Ponte Necessária (São Paulo, Ática, 1990|; sobre a metátora do tradutor como construtor de pontes ver também Hönig, 1997, p. 19 
360 aproveitamento da sabedoria e até da superstição popular se encontra no livro todo mas de maneira concentrada na segunda parte, intitulada $O$ Homem, III subcapítulo, que comeca com a famosa frase "O sertanejo é, antes de tudo, um forte", assim como nos dois subcapítulos subseqüentes. ver Cunha, 1985, pp. 179-255

37 Os padrões conceituais ou estéticos para explicar o Brasi provêm da geografia, da geoogia, da história, das religiõe ou da literatura do Velho Mundo. Euclides fala no extinto "Himalaia brasileiro", en "ciclópicos coliseus", en cânions" "menires", também em "paisagens alpestres" $\mathrm{C}$ nha, 1985, p. 94). O Brasil visto por dentro e por fora. mês de março é caracterizado como de "primavera" (idem, p. 195). É evocada várias vezes a visão que tiveram do Brasil os primeiros descobridores, os "forasteiros" dos tempos coloniais

38 São as últimas palavras de Os Sertões, espécie de legado ao leitor e ao tradutor, até hoje de óbvia atualidade.

39 Euclides, que incorporou tantos estrangeirismos no seu livro to davia tão genuinamente bras leiro, conseguiu, junto com ou tros "sertanistas" como Guima ães Rosa, Graciliano Ramos, Glauber Rocha, incorporar pelo menos uma palavra aos dicionários de várias línguas européias, sertão; ver Duden, 1993 95, vol. VI, verbete Sertão como um etnógrafo meio romântico, pela vida patriarcal, quase bíblica do sertanejo, pela simbiose em que vive com a natureza, e pelo seu folclore, registra e quase continua a auto-representação do povo e de seus cantadores, citando-a e enquadrando-a na linguagem da ciência e da história, praticando uma tradução intralingual, do português do sertão ao português dos letrados urbanos e cosmopolitas, "sertanizando-o" até certo ponto, trabalho continuado por posteriores intérpretes da sertanidade, entre os quais Graciliano Ramos e Guimarães Rosa (36).

Outro método tradutório usado por Euclides vai pelo caminho inverso, às vezes se encontrando com o primeiro a meio caminho. Leva a erudição européia ao sertão, jogando sobre ele sua rede terminológica e conceitual, traduzindo concreta e metaforicamente - os fenômenos desconhecidos do sertão para a linguagem e o ideário do Velho Mundo, com os seus termos científicos, antropológicos ou filosóficos, seus modelos interpretativos, conceitos ideológicos, conhecimentos geográficos, lançando mão de um sem-número enciclopédico de metáforas, alegorias, parábolas, antonomásias ou classificações, estabelecendo filiações, afinidades, analogias e sistematizações por vezes audazes, tomadas do inventário da história universal e de quase todas as ciências, misturando história natural e história humana.

Por que explicar o sertão via Europa, Ásia e África? É que o Velho Mundo, a sua terminologia, os seus códigos intelectuais e éticos eram bem mais familiares aos letrados brasileiros do que a realidade do interior do seu próprio país. A intenção do autor, enquanto patriota, era justamente fazer com que eles voltassem o olhar imbuído de coisas européias para o interior brasileiro, sem abandonar o cosmopolitismo, necessário para a compreensão do Brasil. As charnecas da Bretanha, a Ásia Menor dos primeiros séculos do Cristianismo, a Arábia, a Palestina ou o Saara, a Europa medieval, as estepes eurasiáticas precisavam ser levados ao sertão, para torná-lo mais familiar, desestranhando-o, designotizando-o parcialmente. Vemo-nos diante de um sertão híbrido, europeizado, asiatizadoe africanizado, de modo que pode ser incorporado ao imaginário da nação e do mundo (37).

A linguagem que utiliza e que cria, embora enriquecida de numerosos termos regionais, é no entanto transregional, panlusitana e até cosmopolita, transcendendo as épocas e as variedades do português, amalgamando palavras e construções sintáticas do Brasil todo, do Amazonas até o Rio Grande do Sul, de Portugal, de Vieira até o Naturalismo e o Parnasianismo, incluindo inúmeros termos técnicos universais. O autor, preocupado com a falta de comunicação e entendimento entre culturas e nações, cria um português que contém numerosos elementos de sua própria tradução para uma língua geral de todos os homens civilizados, em que todos, também os seres emudecidos e vencidos, incluindo as plantas, os animais e as pedras sofridas, tenham vez e voz, para que se possa superar "as loucuras e os crimes das nacionalidades" (38).

A comparação e a equiparação, por mais elucidativas que sejam, tendem a subordinaro desconhecido ao já conhecido, tolhendo-lhe a sua singularidade, sua imponência, sua força. O artista em Euclides, ciente desse perigo, neutraliza-o, principalmente com recursos literários e até ficcionais, ao manter o sertão e sua guerra no semimistério, ao enfatizar sua alteridade, sua resistência às categorizações e explicações, sua grandiosidade, transformando-o em mito nacional e saga universal. Ele vai, durante a redação do livro, freando um pouco a tendência comparativa, para abrasileirar a sua visão do Brasil, denominando-o e explicando-o mais com recursos nativos. $\mathrm{O}$ livro que ia se intitular A Nossa Vendéia, acabou sendo nacionalizado como Os Sertões, título autóctone, auto-referencial, no qual o Brasil não se define mais pela semelhança com aspectos do antigo continente colonizador, mas dele se emancipa (39).

Podem-se portanto observar dois procedimentos intelectuais e lingüísticos complementares: por um lado o sertão é integrado na cultura universal, é elevado, 
nobilitado, inclusive com seus elementos misteriosos e desconcertantes, como uma das grandes paisagens do imaginário mundial. Por outro lado a cultura universal explica o sertão, o que relativiza a sua particularidade e incompreensibilidade. O sertão é terminológica e cognitivamente domado, esclarecido, explicado, porém consegue manter boa parte de sua misteriosidade que também é exemplaridade, pois, sendo palco de um drama paradigmático de âmbito mundial, ele até influi na civilização que provoca a desmascarar-se em toda a sua brutalidade. É tipicamente euclidiana a vacilação entre o desejo de analisar e esclarecer tudo, atitude do escritor científico, e de manter a cor local, um certo encantamento, o respeito pelo alheio, obscuro e até sinistro, atitude do escritor poético, ao passo que como historiador e antropólogo ele estaria entre os dois pólos. A atitude iluminista está ligada à esperança na perfectibilidade ou pelo menos reformabilidade do sertão e da civilização, assim como na conciliação entre os dois, ao passo que a atitude poética é profundamente trágica, exceto breves momentos líricos, ainda que não haja homologia total entre as antíteses: iluminismo versus encantamento, por um lado, e reformismo versus tragicidade resignada, por outrolado.

Essa estratégia discursiva na representação da realidade, com sua oscilante eqüidistância entre o descobrir e o encobrir, a incorporação do estranho ao conhecido e o estranhamento do conhecido, caracteriza, grosso modo, também a atividade tradutória ao longo da sua história, principalmente nos últimos dois séculos. Tradutores e pensadores como Hölderlin, Voss, Goethe, Schleiermacher, Benjamin, Berman ou Campos, com muitas diferenças entre si no grau de radicalidade, dedicaram-se a equacionar esses dois tipos opostos de exigências: esclarecer e ao mesmo tempo preservar o estranho (40).

Euclides portanto não traduz apenas do português ao português, mas está com um pé no francês e nas outras línguas européias, numa língua comum da civilização mundial, rumo talvez à língua pura da hu- manidade, na acepção de Benjamin. Realiza elementos de uma tradução interlingual a ser continuada por seus tradutores (41). Pois se aproveita exaustivamente os recursos da língua portuguesa em todas as suas dimensões e ramificações, acentua também os seus traços transculturais e translinguais. Grande parte das dificuldades com que se vêem às voltas o leitor e o tradutor provém da extrema riqueza vocabular, cheia de regionalismos, arcaísmos, termos técnicos, eruditos e estrangeiros, dos apelos que o leitor-tradutor implícito faz à nossa cultura geral, necessária para realizar os significados da obra e tomar uma atitude em relação aos eventos narrados e à história universal Euclides não inova como os modernistas, não inventa nenhuma palavra, nenhum elemento estilístico, é profundamente conservador em relação ao material linguiístico, mas a maneira extremada de que usa e abusa dos recursos tradicionais e contemporâneos do português, da retórica e poética ocidental, é inédita, ao mesmo tempo arcaica e moderna na sua mestiçagem discursiva, quase sempre elevada e sublime, mesmo na sua estética da feiúra que lembra o Naturalismo.

São elucidativas neste contexto as próprias observações do autor sobre a traduzibilidade de Os Sertões para o francês. Já em 1897, antes de ter escrito a primeira linha do livro, havia tratado de procurar um tradutor para o francês, ou seja, escreveu Os Sertões visando não apenas o leitor brasileiro europeizado, mas o leitor francês e através dele os intelectuais da civilização internacional, da qual o idioma de Renan e Taine era língua geral, até a Primeira Guerra Mundial. Em 15 de maio de 1900, dois anos antes de concluir Os Sertões, escreveu ao seu eventual tradutor, o poeta baiano Pethion de Villar:

“Talvez [o livro] não faça jus à consagração de uma versão para o francês a que espontânea e cavalheirescamente te propuseste quando aí estive. Transplantado à mais vibrátil das línguas, por um parisiense dos trópicos, temo que o meu estilo, algo bárbaro, não se afeiçoe a tão delicado relevo" (42).

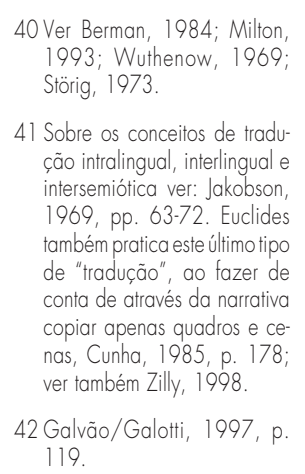

40 Ver Berman, 1984; Milton, 1993: Wuthenow, 1969; cão intralingual, interlingual intersemiótica ver: Jakobson, 1969, pp. 63-72. Euclides em pratica este ultimo fipo copiar apenas quados e cenas, Cunho $1985, p, 178$; 2 Galvão/Galotti, 1997, p. 119 
Sabia ou intuía que vigorava na França o ideal da belle infidèle, segundo o qual uma tradução tinha que se adequar ao ideal estilístico de clareza apolínea, e que seria difícil resgatar algo do estilo híbrido, meio positivista, meio barroco, altamente retórico, rebuscado, maneirista quase, com sua sinonímia transbordante e seus períodos sintáticos amontoando-se atravancadoramente. Nota-se porém o seu desejo de que a tradução justamente deixasse transparecer esses traços "bárbaros", arrevesados, desmesurados, hiperbólicos, um estilo escrito "com cipó”, no dizer de Joaquim Nabuco, com pretensão mimética em relação à realidade inóspita, ínvia, áspera, mas grandiosa do sertão, avessa a uma representação amena, comedida, ponderada (43).

\section{UM LIVRO QUE PEDE PARA SER}

\section{TRADUZIDO}

Coli e Antoine Seel, de 1993

tentou, com êxito, seguir o tro

dutor implícito do original; ve Cunha, 1947; 1993. A primeira tradutora para o francês Sereth Neu, definiu o proble ma da seguinte maneira, justiff cando implicitamente a estraté gia da belle infidèle: "Dans jeu des assonances qui est à la base même du langage, le brésilien apparaît comme un paysage de montagnes e de vallées, avec mille échappées nouvelles, avec des points de vue ou des recoins inattendus, avec des envolées vers les sommets. Son accent tonique évoque l'idée d'une mélodie dont le thème monte, descend hésite, avant de retomber dans le silence. Le français, c'est la plaine, unie, précise, subtile auxhorizons nuancés, dans des lointains bleus e clairs. "ICu nha, 1947 p. VIII. Uma relação das traduções publicada até 1990 se encontra em Garcia, 1995, pp. 17-18.

Os primeiros críticos, como José Veríssimo, ainda que quase unânimes no elogio e até no entusiasmo com a obra em se conjunto, esbarraram no "gongorismo" do autor que teria "viciado seu estilo [...], so brecarregado a sua linguagem de termos técnicos, de um boleio de frase como quer que seja arrevesado, de arcaísmos e sobretudo de neologismos, de expressões obsoletas ou raras, abusando freqüentemente con tra a índole da língua $[\ldots]^{\prime \prime}$. Ve Riedel/Viegas, 1996, p. 19 neo ao mesmo tempo (46).

Já na “Nota Preliminar”, o escritor-historiador deixa claro que o tema do livro não é só a guerra de Canudos, nem só a construção da nação brasileira mas a história da civilização, na sua expansão e luta com culturas atrasadas, periféricas, temática bem moderna, ainda que ele expresse suas considerações na terminologia socialdarwinista da época. Se Euclides escreve o livro "ante o olhar de futuros historiadores" (47), não pensa somente nos historiadores brasileiros, que naquele tempo existiam em número ínfimo. Dirige-se ao público brasileiro e internacional, à posteridade, ao futuro, à História una, com maiúscula, que congrega a humanidade de todos os tempos. "A História não iria até ali” (48), não iria ao "homizio" que é o sertão, terra de crimes, do esquecimento e da impunidade. Todavia, a História foi até ali, representada por seu cronista e advogado Euclides da Cunha, para que escrevesse seu relatorequisitório, obra historiográfica com fortes conotações morais e jurídicas, destinada quase que hegelianamente não ao Juízo Final mas ao Juízo Universal que somos todos nós.

Na mesma página termina um dos subcapítulos da última parte, "Últimos Dias", com a conhecida frase: "Mas que entre os deslumbramentos do futuro caia, implacável e revolta; sem altitude, porque a deprime o assunto; brutalmente violenta, porque é um grito de protesto; sombria, porque reflete uma nódoa - esta página sem brilhos...".

A afirmação sobre a falta de brilhos tem que ser relativizada, pois o escritor acende diante dos nossos olhos todo um fogo de artifício retórico-poético e desdobra toda uma arte encenatória, feito um prestidigitador, justamente para dar um brilho sombrio e sublime ao seu livro, na sua luta contra o esquecimento. Não é porém o fulgor das guerras clássicas, de cujas representações grandiosas se lembra com uma mistura de admiração e ironia e que no fundo lamenta um pouco não poder seguir na sua narrativa sobre a guerra: “[A História] Afeiçoara-se a ver a fisionomia temerosa dos povos na 
ruinaria majestosa das cidades vastas, na imponência soberana dos coliseus ciclópicos, nas gloriosas chacinas das batalhas clássicas e na selvatiqueza épica das grandes invasões. Nada tinha que ver naquele matadouro" (49).

O autor não deixa dúvida de que inscreve essa guerra civil feia, criminosa, ordinária, na História com $\mathrm{H}$ maiúsculo, exemplificando com ela a sua pessimista visão da história. Considera a guerra ao mesmo tempo uma tragédia, eternizada num belo monumento literário, e um crime bárbaro, de que acusa o Brasil civilizado e a civilização toda, perante as divindades secularizadas que são a História e a Ciência, que espera façam um dia justiça.

E o livro termina com as três famosas frases: "Que a ciência dissesse a última palavra. Ali [no crânio de Antônio Conselheiro] estavam, no relevo de circunvoluções expressivas, as linhas essenciais do crime e da loucura...[§] É que ainda não existe um Maudsley para as loucuras e os crimes das nacionalidades..." (50).

Nas duas primeiras frases, a ciência aparece, no discurso indireto livre, como suprema autoridade dos oficiais e dos médicos cientificistas, que levaram o crânio do inimigo morto triunfal e macabramente para Salvador e dos quais Euclides se distancia pela ironia do tom, questionando o valor da frenologia, pois sabe que os exames do dr. Nina Rodrigues não tiveram resultados esclarecedores. Na frase final, que por si só constitui um subcapítulo, ele reivindica uma ciência melhor, em nível internacional, para explicar as loucuras e os crimes, as violências e as guerras de grupos sociais, das nações, dos Estados, não apenas no sertão, mas no mundo. Termina o livro reivindicando outro, uma continuação de Os Sertões, com temática mais transnacional ainda, um estudo sobre as causas das barbáries antigas e modernas, para o qual invoca não uma musa, mas a autoridade de um psiquiatra inglês conhecido por seu livro sobre crimes e loucuras de indivíduos, a fím de que outro sábio o complemente com pesquisas sobre a mes- ma temática, mas voltadas para as coletividades. Intuía que a violência não se pode analisar exclusivamente ao nível individual ou familial, ou da hereditariedade. As reticências convidam o leitor a especulações a esse respeito, uma delas podendo ser a conjetura de que Euclides pode se ter considerado a si mesmo como o tal sábio.

As ferocidades cometidas em Canudos lançam luz sombria sobre a civilização que deixa de ser civilizada nas suas periferias. Vemo-nos mais uma vez diante de uma questão de filosofia da história que transcende de longe a guerra no sertão, fechandose o ciclo de reflexões históricas iniciado na "Nota Preliminar", mas desta vez sem a forte conotação racista do começo do livro. Como escritor científico, que não escreve uma epopéia, embora esteja imbuído do espírito desse gênero, Euclides não pode invocar uma musa, mas as freqüentes referências a instâncias universais como futuro e história, ciência, humanidade, civilização desempenham parcialmente esse papel. Devem ajudar o "narrador sincero" (51) como ele se autodenomina, na sua difícil tarefa de pesquisar e expressar a verdade sobre Canudos, assinalando ao leitor que trata ao mesmo tempo das grandes questões da humanidade em cuja tradição escrita ele insere o seu texto. Nota-se tanto no enredo como em alguns comentários o vislumbre de uma dialética da civilização que, para progredir e se expandir, engendra o mal que afirma combater, traindo-se a si mesma, observação que um século mais tarde, depois de duas guerras mundiais e genocídios horrorosos, parece-nos mais plausível talvez do que aos contemporâneos do autor, que se perfila diante de nós como cronista e profeta dos crimes da civilização: "Nesse investir, aparentemente desafiador, com os singularíssimos civilizados que nos sertões, diante de semibárbaros, estadearam tão lastimáveis selvatiquezas, obedeci ao rigor incoercível da verdade" (52).

O leitor, e portanto o tradutor, é convidado a ler, entender e transpor para a sua cultura, em um livro só, três modos de enfocar, de pesquisar e de representar essa
44 Cunha, 1985, p. 241

$45 \mathrm{Um}$ dos elementos do tradutor implícito em Os Sertões é a primeira pessoa do plural, que geralmente significa, além do plural da modéstia: nós os le trados, cultos, civilizados das grandes cidades do Brasil também: nós, os brasileiros inimigos de Canudos: mas além disso pode significar: nós, os homens civilizados do mundo inteiro.

46 Cunha, 1985, p. 86,221 584. Ver também o índice onomástico em: Cunha, 1998 A crítica da época logo equiparou Os Sertões aos grandes nomes da literatura universal (ve Riedel/Viegas, 1996), a Tolstoi (p. 13), Góngora (pp. 19, 60 esta última aliás, a única comparação com intenção menos elogiosal, Michelet (p. 22) Scott (p. 23), Xenofonte (p. 23) Flaubert (p. 23), Dante (p. 31) a Bíblia lo Apocalipse, pp. 23 e 55. os profetas de Sião p. 54), Ernest Renan (p. 36) Humboldt, Martius, Bates (todos p. 58). Além disso já as primeiras resenhas louvaram o cará ter pictorial e escultural das des crições, comparando-as com a fotografia (p. 22), com Rembrandt, com Michelangelo.

47 Cunha, 1985, p. 85

48 ldem, ibidem, p. 538

49 ldem, ibidem, p. 538.

50 ldem, ibidem, pp. 572-3. As duas últimas frases do livro são separadas não apenas por novo parágrafo mas também pela diferença dos modos na rativos, apresentando-se a primeira como discurso indireto livre e a segunda como comen tário do narrador; sendo as duas ligadas simetricamente pela figura do quiasmo. O título do livro a que se alude é Le Crime et la Folie, na tradução francesa de 1891, portanto ele é invertido por Euclides; ve Andrade, 1960, p. 255 Henry Maudsley 11835 1918), médico e psiquiatro inglês, adepto do determinismo evolucionista, notabilizou-se naquela época por suas pesquisas sobre as causas $d a$ criminalidade que viu em perturbaçōes mentais, hereditárias e influenciadas pelo meio.

51 Cunha, 1985, p. 86

52 ldem, ibidem, p. 584. 
53 Essas três abordagens - a científica, a sociológica, a literária - correspondem àquilo que sociólogo alemão Wol Lepenies chama de "As Três Culturas", não diferenciando porém muito claramente entre a literatura e a crítica literária ver Lepenies, 1996. Essa tríad discursiva foi detectada clara mente por a guns críticos da primeira hora, por exemplo por da Penha e sobretudo por Jos Veríssimo; ver Côrtes Riedel/ Viegas, 1996, pp. 11, 19; ve também p. 33, onde é repro duzido o parecer sobre a ad missão de Euclides da Cunha ao $I H G B$, de 1903

54 Há meio século, nos Estados Unidos ainda prevalecia o intere se informativo e erudito, de modo que o tradutor para o inglês deu ao livro um cunho pre ominantemente acadêmico realçando sua função referencia e publicando-o numa editora un versitária, ao passo que as recentes traducões para o francês e para o alemão acentuam a função poética do texto; ver Cunha, 1944; 1947; 1993 1994. Um critério que salta aos olhos é a colocação das indispensáveis notas explicativas do tradutor que na versão inglesa como também na primeira versão francesa se encontram no pé da página, ao passo que quase todos os demais tradutores, para não intervir no fluxo da leitura e para dar ao livro, ja pelo layout, um caráter mais lite rário, preferiram notas finais e/ ou um glossário, como apênd$\mathrm{ce}$, que o leitor pode, se quiser gnorar mais tacilmente durante a leitura já que consultá-las exige esforço e curiosidade ad cionais. Sobre a versão inglesa ver Milton, 1997

Um dos recursos de acentuar na versão alemã a literariedad do texto consiste em dar preferência, na translação de termo cientificos ou técnicos, ao termo baseado no léxico de origem germânica nos casos em que a língua alemã oferece duas alternativas: um termo mais académico, geralmente de origem greco-latina; e um termo or popular, ora traduzido como em préstimo semântico, com radcal de origem germânica; por exemplo "podômetro" pode ser traduzido como "Podometer" ou como "Schritzähler"; "cautério" pode ser "Kauterium" ou eventualmente, "Brennschere"; "animalidade primitiva" pode ser "primitive Animalität" ou eventualmente, "ursprüngliche Tiernatur". " " " natureza estereografa-se" não dá para traduzir literalmente, mas poder-se ia escrever "die Natur tritt stereographisch hervor", ou "bietetsich stereographisch dar", "bietet einen stereographischen Anblick podendo-se substituir talvez stereographisch" por "plastisch", palavra um pouco plastisch, palavra um pouco
mais agradável ao ouvido. Soando a palavra realidade, correspondendo a três discursos que se haviam distanciado cada vez mais ao longo do século XIX e cuja fusão era inusitada na Europa da época: o discurso científico, o historiográfico-antropológico, o literário (53). Ou seja, Euclides procura conter ou até reverter a crescente diferenciação entre os modos de apropriação e de representação da realidade que no Iluminismo e na primeira métade do século XIX muitas vezes ainda se encontravam em um autor só, d'Alembert, Diderot, Humboldt, Goethe, Martius, Saint-Hilaire e muitos outros. Opõe-se à crescente divisão e especialização do trabalho intelectual ocorrida no século XIX, tentando superar a distância entre: 1) as ciências naturais, empíricas, exatas, quantitativas, 2) as ciências sociais e históricas, hermenêuticas, qualitativas, e 3) a abordagem literária, empática, imaginativa, já que os dois primeiros modos de representação se averiguaram insuficientes para captar a complexidade e a contraditoriedade dos fatos. Esforça-se por aplicar, reunir, fundir os modos cognitivos e discursivos correspondentes a essas três áreas na luz dos conhecimentos e teorias do seu tempo, para narrar a Verdade sobre o sertão, a guerra, a civilização, a alma humana, incluindo aspectos de opacidade, incoerência, misteriosidade. Empreendimento hercúleo, sobre-humano, impossível quase, mas coroado de um resultado que, se é algumas vezes desigual e incoerente, nem por isso deixa de ser convincente, elucidativo, valioso em todos os três campos da atividade intelectual, principalmente como obra historiográfica e literária. Essa tríade discursiva é ao mesmo tempo uma incumbência ao tradutor, que deve tentar recriá-la na sua língua, reponderando cautelosamente a correlação entre os três discursos, dando menos ênfase à vertente científica, hoje mais datada (54).

Na obra euclidiana se opõem e se revezam o cientificismo por um lado e o ceticismo para com as ciências, inclusive as sociais, por outro lado, sendo de um modo geral as duas atitudes dominadas pela percepção tão exata quanto impressionista e imaginosa do literato, que vê e recria a realida- de com olhar de pintor, fotógrafo ou quase cineasta, induzindo o leitor e portanto o tradutor a vê-la e recriá-la do mesmo jeito. É programática a reflexão que antecede a conhecida frase "O sertanejo, antes de tudo, é um forte":

"Prossigamos considerando diretamente a figura original dos nossos patrícios retardatários. Isto sem método, despretensiosamente, evitando os garbosos neologismos etnológicos. [\$] [...] Sejamos simples copistas. [\$] Reproduzamos, intactas, todas as impressões, verdadeiras ou ilusórias, que tivemos quando, de repente, [...] demos de frente, numa volta do sertão, com aqueles desconhecidos singulares, que ali estão-abandonados-há três séculos"(55).

Euclides, com toda a força evocativa da sua retórica erudita e no entanto sensorial, subordina, em última instância, os discursos científico e histórico-antropológico ao literário, que evoca o recente passado através da descrição pictorial e da narração teatral, como se guiasse os leitores por uma exposição de quadros e por um anfiteatro com cenas de uma tragédia, transmitindolhes informações, emoções, perplexidades (56). Predominam, como intenções de efeito, a comoção trágica e a indignação moral, além do prazer estético. Prazer que se deve a duas qualidades quase contraditórias do livro: o seu caráter monumental, imponente, autoritário, impenetrável, temível quase, por um lado, e por outro o seu caráter sensorial, plástico, sonoro, empolgante, persuasivo, apelativo, provocando atitudes tão opostas quanto o culto, a veneração respeitosa por um lado, e o uso pragmático e familiar como fonte de informações e citações por outro. Esses traços estéticos opostos pressupõem dois gêneros de leituras, uma mais passiva, humilde, poética, emocional e empática, de qualquer forma aceitando muitas incompreensões, e outra mais esforçada, mais árdua, mais cognitiva, obrigando o texto a relaxar o seu hermetismo. O tradutor, naturalmente, procura abranger as duas leituras.

Recentes mudanças na vida intelectual 
e nas ciências humanas salientam a atualidade de Os Sertões como discurso híbrido poético-historiográfico-científico, modificando o papel do leitor e do tradutor inscrito no livro. Se a simultaneidade e até fusão de abordagens intelectuais tão díspares num mesmo livro era na época quase um sinal de atraso, explicável em um país sem universidades, sem cursos de ciências exatas fora da medicina e da engenharia, sem cursos de ciências sociais e de letras, hoje em dia essa poetização do discurso científico e sociológico, essa renúncia ao juízo coerente e ao domínio total da análise e da sistematização, essa plurivocidade também conquistaram boa parte da historiografia e da antropologia. A atitude de observador participante que Euclides reveste, a sua encenação presentificadora dos eventos, apesar do seu gesto por vezes professoral e autoritário, todos esses traços supostamente datados de Os Sertões podem ser lidos como prenúncios da nova historiografia, de um Ginzburg, Duby, Le Roy Ladurie, uma escrita histórica menos categorial e analítica, antes cênica, encenatória, empática, dando voz aos perdedores da história, aproximando-se daquilo que o antropólogo Clifford Geertz chama de "descrição densa" (57).

Ao passo que a historiografia oficial na Europa de cem anos atrás considerava pouco profissional o estudo de eventos recémocorridos, parecendo Euclides, sob esse aspecto, adepto aparentemente ingênuo, amadorístico e retardatário da tradição greco-romana e do ensaísmo iluminista, visto a partir de hoje ele, ao contrário, surge como autor moderno, pois de algumas décadas para cá a história do tempo presente virou disciplina respeitadíssima nas universidades do mundo inteiro.

A literariedade do livro não é uma qualidade invariável, visto que o seu grau e o seu caráter dependem em grande parte do leitor, do seu horizonte de expectativa, do seu interesse cognitivo assim como da conjuntura histórica. $\mathrm{Na}$ medida em que aumenta a distância cronológica e cultural entre o ato da leitura e a primeira publicação do texto, o seu caráter pragmático, as suas funções referenciais e apelativas vão perder uma parte de sua importância, de modo que o clássico euclidiano hoje em dia, principalmente fora do Brasil, é mais literário do que era no Brasil de 1902. Se os eventos narrados e o seu arcabouço teórico passam cada vez mais ao segundo plano, cabe ao tradutor, dentro da mencionada tríade discursiva, realçar a vertente literária, sem negligenciar as outras. Para o leitor estrangeiro de hoje em dia importa menos se certos detalhes do relato correspondem aos fatos, mais relevantes são o estilo e o modo de narração, a exemplaridade dos temas, as atitudes morais e filosóficas do narrador, vistas diante dos últimos cem anos de civilização ameaçada por ela mesma que transcorreram desde a publicação de Os Sertões.

\section{BIBLIOGRAFIA}

ANDRADE, Olímpio de Souza. História e Interpretação de "Os Sertões". São Paulo, Edart, 1960.

ARROJO, Rosemary. Oficina de Tradução: a Teoria na Prática. São Paulo, Ática, 1986.

ASHCROFT, Bill; GRIFFITHS, Gareth e TIFFIN, Helen (orgs.). The Empire Writes Back: Theory and Practice in PostColonial Literature (New Accents). London, Routledge \& Kegan Paul, 1990.

ASSIS, Joaquim Machado de. "Notícia da Atual Literatura Brasileira: Instinto de Nacionalidade", in J. M. A., Obra

Completa, organizada por Afrânio Coutinho. 3 vols. Rio de Janeiro, Nova Aguilar, 1986, vol. III, pp. 801-9.

BARCK, Karlheinz. "A Tarefa de Traduzir A Tarefa do Tradutor no Rio de Janeiro", in Walter Benjamin, A Tarefa do

Tradutor. Tradução de Dirce Riedel et alii, revisão de Johannes Kretschmer. Rio de Janeiro, Ueri/Instituto de Letras, 1994 , pp. 33-40.

BENJAMIN, Walter. "Die Aufgabe des Übersetzers", in Schriften, hrsg. v. Th. W. Adorno und Gretel Adorno unter

stereographisch" bastantefeio em alemão, optei por " die Natur meisselt sich heraus" o que sig. nificaria aproximadamente "a natureza esculpe-se" ou "cinzea-se", solução menos científica, certo, porém mais plástica e mais acessivel, e sobretud mais sonora, mais poética. De um modo geral os termos científicos alemães de origem es trangeiro, principalmente por sua sonoridade estranha, despoetizam oestilo e, enquanto signos imotivados, com seus radicais desconhecidos ao leitor comum, são pouco sugestvos; ao passo que as palavras menos eruditas de origem germânica, geralmente compostas, têm sonoridade mais agradável, sendo além disso mais sensoriais e sugestivas, po seu parentesco reconhecíve com outras palavras, ou seja por seu caráter de signos motivados. Devido à pouca elegância fônica de termos científicos em alemão, é difícil escrever um texto acadêmico ou instrumental num estilo sensorial e ex pressivo.

55 Cunha, 1985, pp. 177-8

56 Ver Zilly, 1998, pp, 13-37. As numerosas metáforas provenientes das artes plásticas e cênicas são elementos do leitor e do tradutor implícito, incitando o leitor e o tradutor uma leitura e reconstituição visualizadora. Vários editores e tradutores de Os Sertões, jusamente para realcar o caráter cênico do livro e também para ornar os longos capítulos mais transparentes através de subdivisões, introduziram intertítulos, tomados ou do pró prio texto euclidiano, ou dos sumários que precedem cada uma das oito partes do livro; ver Galvão, 1985 p. 23 O intertítulos, importante instrumento para direcionar a aten ção do leitor, podem aumenar o suspense, o que tentei por exemplo no cap II da sétima parte do livro, "Nova Fase da Luta", em trecho intitulado por alquns editores de "Rebate Falso" Cunha 1966 vol. 442) e que eu intitulei na radução alemã como "Alarm", de modo que só no final da quela página fica claro que se trata de um rebate falso.

57 Rüsen, 1997. Diferentemente de autores pós-modernos Euclides, como escritor científ co do século XIX mantém o conceito da História una e teoricamente, cognoscível. Sua empatia com os sertaneios com parte dos soldados não constitui um princípio $d a$ narativa toda, e apesar da multiplicidade de impressões, perspectivas e vozes ele só periodicamente abandona hegemônica visão racional do narrador erudito que procura pairar acima das contingências da realidade, para entendê la e explicá-la. 
Mitwirkung von Friedrich Podszus, Band I. Frankfurt am Main, Suhrkamp, 1955, p. 40-54.

. A Tarefa do Tradutor. Tradução de Dirce Riedel et alii. Rio de Janeiro, Ueri//Instituto de Letras, 1994.

BERMAN, Antoine. L'Épreuve de l'Étranger: Culture e Traduction dans l'Allemange Romantique. Herder, Goethe,

Schlegel, Novalis, Humboldt, Schleiermacher, Hölderlin. Paris, Gallimard, 1984.

. "La Traduction et la Lettre, ou: L’Auberge du Lointain", in G. Granel, A. Jaulin, G. Mailhos, H.

Meschonnic, Les Tours de Babel: Essais sur la traduction. Mauvezin, Trans-Europ-Repress, 1985, pp. 33-150. . Pour une Critique des Traductions: John Donne. Paris, Gallimard, 1995.

"Commentaire de la Tâche du traducteur de Walter Benjamin", in Césure: Revue de la Convention

Psychanalytique. Paris, no 11, 1996, pp. $11-7$.

BORGES, Jorge Luis. "Pierre Menard, Autor del Quïjote", in Obras Completas 1923-1972. Buenos Aires, Emecé, 1974,

pp. 444-50 [também publicado em: J. L. B., Ficciones, Madrid, El libro de Bolsillo/Alianza, 1971, pp. 47-59].

CAMPOS, Haroldo. "Da Tradução como Criação e como Crítica", in Metalinguagem \& Outras Metas: Ensaios de Teoria e Crítica Literária. São Paulo,Perspectiva, 1992, pp. 31-48.

. "Da Tradução à Transficcionalidade", in 34 Letras, no 3. Rio de Janeiro, 1989, pp. 82-101.

. "A Língua Pura na Teoria da Tradução de Walter Benjamin", in Revista USP, São Paulo, no 33, USP,

março-maio/1994, pp. 160-70.

CUNHA, Euclides da. Os Sertões. Edição crítica de Walnice Nogueira Galvão. São Paulo, Brasiliense, 1985 [1a edição:

Os Sertões (Campanha de Canudos), Rio de Janeiro, Laemmert, 1902].

Os Sertões: Campanha de Canudos. Edição crítica de Walnice Nogueira Galvão. São Paulo, Ática, 1998.

Obra Completa. Org. por Afrânio Coutinho. 2 vols. Rio de Janeiro, Aguilar, 1966.

. Los Sertones. Tradução de Benjamín de Garay. 2 vols. Buenos Aires, Mercatali, 1938.

. Los Sertones: I Tragedia del Hombre Derrotado por el Medio. Buenos Aires, Claridad, 1942.

L Los Sertones. Tradução de Estela dos Santos. Caracas, Biblioteca Ayacucho, 1980.

Rebellion in the Backlands (Os Sertões). Tradução de Samuel Putnam. Chicago, The University of

Chicago Press, 1944.

. Les Terres de Canudos: Os Sertões. Tradução de Sereth Neu. Rio de Janeiro, Caravela, 1947 [Título na

capa: Les Terres de Canudos: Grand roman historique traduit du portugais par Sereth Neu].

. Hautes Terres: La Guerre de Canudos. Tradução de Jorge Coli e Antoine Seel. Paris, Metaillé, 1993.

. Krieg im Sertão. Tradução de Berthold Zilly. Frankfurt am Main, Suhrkamp, 1994.

DUDEN: Das große Wörterbuch der deutschen Sprache, 8 vols., Mannheim; Leipzig; Wien. Zürich, Dudenverlag, 1993-1995.

EAGLETON, Terry. Teoria da Literatura: uma Introdução. Tradução de Waltensir Dutra. São Paulo, Martins Fontes, 1997.

GALVÃo, Walnice Nogueira e GALOTTI, Oswaldo. Correspondência de Euclides da Cunha (ativa). São Paulo, Edusp, 1997.

GALVÃo, Walnice Nogueira. "Introdução", in Euclides da Cunha, Os Sertões. Edição crítica de Walnice Nogueira

Galvão. São Paulo, Brasiliense, 1985.

GARCIA, Marcia Japor de Oliveira e FürSTENAU, Vera Maria. O Acervo de Euclydes da Cunha na Biblioteca Nacional. Campinas, Editora da Unicamp; Rio de Janeiro, Biblioteca Nacional, 1995.

GERZYMISCH-ARBOGAST, Heidrun. Übersetzungswissenschaftliches Propädeutikum. Tübingen; Basel, Francke, 1994.

HÖNIG, Hans G. Konstruktives Übersetzen. Tübingen, Stauffenburg, 1997.

HIRSCH, Alfred (org.). Übersetzung und Dekonstruktion. Frankfurt am Main, Suhrkamp, 1997.

ISER, Wolfgang. Der Implizite Leser: Kommunikationsformen des Romans von Bunyan bis Beckett. München. Fink, 1994. . 0 Fictício e o Imaginário: Perspectivas de uma Antropologia Literária. Tradução de Johannes

Kretschmer, Rio de Janeiro, UERJ, 1996.

Editora 34, 1996.

O Ato da Leitura: uma Teoria do Efeito Estético. Tradução de Johannes Kretschmer. vol. 1. São Paulo,

IYER, Pico. "The Empire Writes Back: Am Beginn einer neuen Weltliteratur?". Tradução de Reinhard Kaiser, in Neue

Rundschau. Frankfurt am Main, Fischer, 1996, ano 107, caderno 1, pp. 9-19.

JAKOBSON, Roman. "Aspectos Lingüísticos da Tradução", in Lingüistica e Comunicação. Tradução de Isidoro Blikstein.

São Paulo, Cultrix, 1969, pp. 63-72.

. "Lingüística e Poética", in Lingüística e Comunicação. Tradução de Isidoro Blikstein. São Paulo,

Cultrix, 1969, pp. 118-62.

LEPENIES, Wolf. As Três Culturas. Tradução de Maria Clara Cescato. São Paulo, Edusp, 1996.

MOSCA, Lineide do Lago Salvador. "A Preservação dos Aspectos Expressivos na Atividade Tradutória: uma Aplicação a 
Os Sertões, de Euclides da Cunha", in Pandaemonium Germanicum: Revista de Estudos Germânicos, o 1. São Paulo, USP/DLM/Humanitas, 1997, pp. 187-98.

MILTON, John. "A Tradução de Samuel Putnam de Os Sertões - Rebellion in the Backlands, de Euclides da Cunha", in Pandaemonium Germanicum: Revista de Estudos Germânicos, no 1.São Paulo, USP/DLM/Humanitas, 1997, pp. 181-5. . O Poder da Tradução. São Paulo, Ars Poética, 1993.

Neve Rundschau, ano 107, caderno 1, “Der postkoloniale Blick: Eine neue Weltliteratur?", Frankfurt am Main, Fischer, 1996.

PAES, José Paulo. Traducão: A Ponte Necessária. São Paulo, Ática, 1990.

RIEDEL, Dirce Côrtes e VIEGAS, Ana Cláudia Coutinho (orgs.). Os Sertões de Euclides da Cunha e a Imprensa da Época. Rio de Janeiro, UERJ, Dep. de Extensão, 1996 (Cadernos do Centro de Estudos Virgínia Côrtes de Lacerda, vol. 1, n. 1). RÜSEN, Jörn. "História entre a Modernidade e a Pós-modernidade", in História: Questões e Debates. Curitiba, UFPr, 1997, v. 14, n. 26/27, jul./dez. 1997, pp. 80-101.

SCHLEIERMACHER, Friedrich. "Ueber die verschiedenen Methoden des Uebersezens", in Hans Joachim Störig (org.), Das Problem des Übersetzens. Darmstadt, Wissenschaftliche Buchgesellschaft, 1973, pp. 38-70.

SCHWARTZ, Adriano. "Instinto de Universalidade", in Folha de S. Paulo, 28/3/1999, Caderno Mais, p. 6.

SÁ-CARNEIRO, Mário. A Confissão de Lúcio. Lisboa, Ática, 1995.

STÖRIG, Hans Joachim. "Einleitung", in Hans Joachim Störig (org.), Das Problem des Übersetzens. Darmstadt, Wissenschaftliche Buchgesellschaft, 1973, pp. VII-XXXIII.

VILLAÇ, Alcides. "Machado de Assis, Tradutor de si Mesmo", in Novos Estudos, no 51. São Paulo, Cebrap, 1998, pp. 3-14.

WUTHENOW, Ralph-Rainer. Das fremde Kunstwerk: Aspekte der literarischen Übersetzung. Göttingen, Vandenhoeck \& Ruprecht, 1969.

ZILLY, Berthold. “Um Depoimento Brasileiro para a História Universal: Traduzibililade e Atualidade de Euclides da Cunha", in Estudos: Sociedade e Agricultura, no 9. Rio de Janeiro, UFRJ/CPDA, 1997, pp. 5-15 (versão ligeiramente ampliada do artigo com título idêntico na revista Humboldt, no 72, Bonn, Inter Nationes, 1996, pp. 8-16).

. "A Guerra como Painel e Espetáculo: A História Encenada em Os Sertões", in História, Ciências, Saúde: Manguinhos, suplemento, vol. V, julho de 1998, pp. 13-37. 